\title{
FACTORS INFLUENCING TEENAGER'S MOTIVATION IN LEARNING ENGLISH IN UZBEKISTAN - A CASE STUDY OF WESTMINSTER INTERNATIONAL UNIVERSITY IN TASHKENT, PRE-FOUNDATION COURSE
}

\author{
Mamadaminova Nigora ${ }^{i}$, \\ Khadjikhanova Sabina \\ Westminster International University in Tashkent, \\ Pre-university Department, \\ Uzbekistan
}

\begin{abstract}
:
Motivation carries a key role while learning a foreign language. Understanding the motivators and factors which impact students' motivation would help to improve the quality of the lessons. Thus, this study aims to identify the main motivator in acquiring the English language among teenage students at the Pre-Foundation course of Westminster International University in Tashkent. The research also finds out general impressions of students towards their teachers, parents, and group mates at the course. Quantitative type of research was implemented. The questionnaire was designed and the teenage students of the Course for Pre-Foundation Studies were invited to complete online survey. The methodology of the study was adopted from Abdul Rahman H., et al (2017) and modified appropriately. According to the current study results, teachers are the motivators with prevalent influence on teenage students' learning, whereas personal attitude and peers also had enormous impact in studying English language. The results of the research can be implied to develop or upgrade teaching methods and improve conditions at the educational centers, private or public secondary schools and lyceums.
\end{abstract}

Keywords: motivation, teenagers, English language, teachers, peers, self-motivation

\section{Introduction}

Learning languages is considered to be a progressive and continuous process which can lead to have changes in students. Rao (2019) claims that as globalization is developing, most people are communicating in English which is internationally recognized language. Knowing a language can assist students' in achieving goals in academic areas, in choosing future occupation and in reaching future goals. Mastering the English language

i Correspondence: email n.mamadaminova@gmail.com 
can be beneficial in the world of education, technology and career. Rao (2019) says that English is the language that is used in different spheres such as trade, telecommunications, scientific publications, entertainment and diplomacy. Most of the teenagers are interested in learning the languages, especially English. According to Win (2018), the learners' interest in learning the English language is the most important factor. If there is a strong desire to learn the English language, the results will be effective and efficient (Saroh, 2019).

Being interested in learning can smooth the process of learning and teaching which can lead to reaching the learning objectives. Motivation is the most crucial in acquiring knowledge. Cenic (2018) claims that motivation can represent the students 'readiness to solve different problems in learning process. Students' motivation depends on different factors such as their interests, curriculum design and teachers' teaching methods. If the student has a strong desire to succeed in learning a language, then she/he can work on herself/himself very hard and have good results. There is a quote by Locke, "Where there is no desire, there will be no industry". Keeping them involved and interested in the lessons can be a great way to have a happy learning process. According to Tianjuan (2019), learning can be fun if the teachers encourage the students by using creative methods in solving the problems during the classes. Teachers' role is very vital in being motivated during the classes.

Different researches were carried out in order to find the ways in enhancing students' motivation in a studying place. According to Munira and Muhsin (2015), the usage of different task based- language teaching methods is essential for students in order to be involved in the classroom activities. Rita (2019) claims if the teachers choose the right methods during the lessons, it can be the reason of having both great motivation and good results in a learning process.

Mackey (2014) claims that the aim of studying the English language is unlimited. However, the motivation is a key factor to succeed in learning a language. With the help of motivation, the learners can reach high levels. Moreover, if the students are highly encouraged, the learners allege positive attitude towards language development Oyshajon (2020).

Taking into consideration all above mentioned factors, it can be assumed that there is no clear assumption that one form of motivation is superior to the other. Particularly, the fact that who can motivate the students: teachers, parents or peers is not fully evident. Hence, there is need for further investigation in this field to have different points and perspectives for acquiring the knowledge about the impact of factors in learning the language. 


\section{Literature review}

\subsection{Motivation}

Motivation is a word derived from "motive" which means wants, desires, drives or needs within the individuals. Different authors have defined the word motivation in variety of ways. Motivation refers to "the reasons underlying behavior" (Guay et al., 2010). According to Filgona (2020) motivation is a term which can be defined as the drive in order to satisfy the people's needs in gaining different skills. Ziahosseini (2008) indicates that "Motivation is a factor determining the extent of people's desire to do an activity". Jowkar, Motlagh, Mirshamsi (2017) claim that if the learners of the language are more motivated, they can succeed more in learning a language. According to Oroujlou, Vahedi (2011) learners are in need of interaction, input and chances for meaningful output not only to make progress but also to support motivation in learning a language. Wilmolmas (2013) claims that motivation plays an important role in learning a language which can lead to a certain degree. According to Alizadeh (2016), motivation provides learners with aims and directions to follow. Moreover, he claims that it is tough to achieve effective learning without motivation. Although the students have surprising language acquisition skills, without motivation they can hardly achieve success in learning a second language (Win, 2018).

Here two types of motivation can be explained which are related to our research.

\subsection{Intrinsic and extrinsic motivation}

There are two types of motivation: intrinsic and extrinsic. Intrinsic motivation when students desire to accomplish the tasks by their own and extrinsic when the teacher creates the environment where the students are motivated. Intrinsic motivation is when the person desires to participate in different activities because he thinks that he is pleasant and attractive (Mahadi, Jafari, 2012). The activity which is done for the person's own pleasure and satisfaction is intrinsic motivation (Deci, 1975).

Extrinsic motivation, on the other hand, is a term which means to do an activity in order to achieve a goal. For example, the learners try to be successful in exams, get good marks and get awards. According to Reiss (2012), extrinsic motivation is considered to pursuit a goal in order to please a parent or win a championship. Rewards or incentives which are external factors may affect students' learning process. (Bain, 2004; Theobald, 2006).

It is essential for the teacher to know two types of motivation (intrinsic and extrinsic) (Mahadi, Jafari, 2012). Relying on both of types of motivations, for creating and developing either of them, the teachers can organize their lessons without any anxiety.

\subsection{Students' self-motivation}

The greatest challenges of education are motivating students so that they can succeed in their studies. Students' motivation is an essential element in order to have high quality 
education. Stroinska (2016) claims that motivation in the classroom is for the teacher when students desire to enter the classes, participate in the lessons and try to get good marks. Students' curiosity to acquire new knowledge and to engage new activities is crucial. According to Cenić, Petrović, Cenić (2018) if the curiosity is not developed, students can face different challenging situations, such as limited students' development and unproductive communication.

Johnson (2017) says that students' learning can be improved because of their own desires and wishes in order to fulfil or perform a task. However, Bain (2004); Theobald, (2006) claim that some of the external factors (awards and prizes) can influence on students' learning. Students who believe themselves to be capable are considered to be motivated rather than the students who think that they are incapable (Seifert, 2004).

\subsection{Parents' impact on a child's motivation}

Parents play a major role in the motivational development of adolescents. When the students feel support of their parents their desire towards studying increases. Pape (1999) states if parents are involved in their children's academic life, those can achieve good results in their studies. Fager and Brewster write about the advantages of involvement of parents in learning. They say that this involvement can improve academic performance which can bring to low rates of dropout. Garrett (1995) gave a speech in Oklahoma Administrator's Conference "the smallest school in America is the family" which demonstrates a crucial role towards the motivation and education of both parents in the family.

Okoza (2012) says that home environment is as vital as school atmosphere. There are several factors which are important to be paid much attention by parents. For instance, if the parents read to their children, if the children are controlled and limited in watching TV and if they change schools for several times. Students can have a profound early impact because of their parents' attitudes, beliefs and expectations in education. "The home environment sharpens the child's initial view of learning" (Okoza, 2012).

\subsection{The influence of teachers on student motivation}

The role of the teacher can be considered as a major factor in all stages of the motivational process. Motivation is thought to be a key in learning which is created and fostered by well prepared and educated teacher. Moreover, motivating, encouraging and helping the learners in difficult situations during the classes show the teacher's enthusiasm and acknowledgment towards the students. Gilakjan, Leong, Sabouri (2012). According to Mahadi, Jafari (2012) in order to have a positive view about the goals students achieved during the classes, the teachers should award the students by giving good grades, degrees and any kind of educational support. Indeed, students ought to feel that all of the efforts are valued by the teacher. As described by Ofoegbu (2004) the factor for having high school development and classroom effectiveness depends on teacher' motivation. 
The teachers 'commitment is believed to be the major factor of effectiveness in learning. (Nir, 2002).

\subsection{Peer's motivation}

Peer learning involves the procedure of students who work together and develop skills of collaboration. Students can construct their own opinions and understanding on what they want to learn. Particularly, they can be involved in searching the data, analyzing and collecting in order to complete the task. As a result, students will be involved in the process socially, intellectually and emotionally Boud (2001). Moreover, Boud (2001) claims when students participate in different activities together, they can give and receive feedback, evaluate each other's performance.

Peer support is important in facilitating language learning in other peers (Olusiji, 2016). Besides, Olusiji (2016) says that peers and classmates play a major role in motivating each other. Similarly, Murphey (1998) claims that peers do not only give support to each other but also can be a role model who can enhance other students' motivation in learning a language. This concept can be assisted that students can learn effectively and accurately from the students particularly, from their peers. Several studies have proven that it is fruitful and effective to facilitate a language learning from peers rather than teachers (Fitz-Gibbon, Reay, 1982). The reason for this can be that there is less formality among the peers.

One of the schools in Hong Kong has investigated Wong (2007) that peer motivation is the most influential factor in learning a language. However, another study conducted among Philippines schools showed that parents were the main encouragement in learning a language (Paran, Tibli, 2009).

As Newton claims "for every action there is an equal and opposite reaction" which can be identified that every kind of motivation received either from their teachers, parents or classmates is equal to the degree of effort students' try to do toward the learning a language.

\section{Methodology}

The aim of the current research is to find out the answer to the question:

1) Whose influence is greater on students' motivation to learn a foreign language?

2) Do teachers motivate their teenage students more than parents

3) How group mates effect during or outside the classes in improving English language?

4) What is the role of self-motivation in achieving the aim of learning/improving English language in teenagers?

The analysis of situation was performed among students of pre-university department of Westminster International University in Tashkent to understand the motivation of students in learning a foreign language. Online tool - google forms was 
used to conduct the current survey, as it is more convenient and open to more participants during the time of pandemic.

Westminster International University in Tashkent (WIUT) is the first international university founded in Central Asia which offers UK qualifications. The course of prefoundation studies is designed to prepare students of different schools or lyceums who wish to study further at WIUT. The main purpose of the course is to improve the English and Mathematics skills of upcoming applicants of the University. The candidates are selected based on the entrance exam for the pre-foundation course. Usually, they are teenagers and sometimes even elder ones those who failed to enter the university in previous years. Candidates for the current course already have at least intermediate and upper-intermediate levels of English language. They usually come from the capital city, Tashkent but sometimes from other regions too.

This study was conducted from May 2 till May 14, 2021. Students of both levels of Basics of Academic English courses were invited to fill in the questionnaire. Overall, 64 responses were collected and three of them were eliminated due to the technical error and mismatch to the target group of the research. Thus, 61 responses were analyzed and discussed further.

Chart 1: Age range of survey respondents

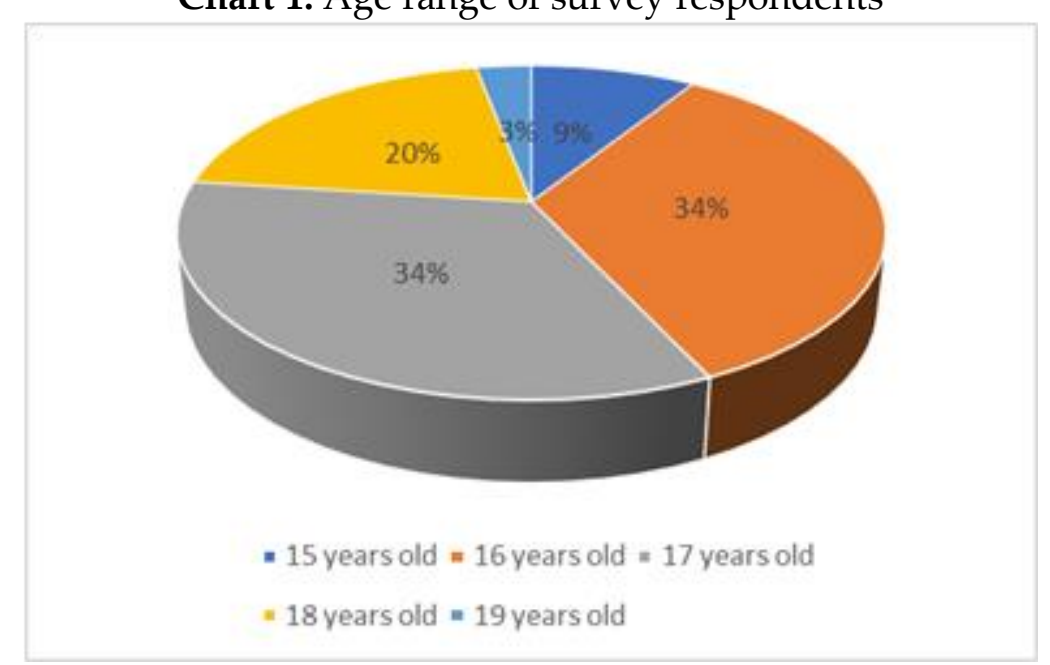

Source: own research results

The survey included 32 (52.5\%) male and 29 (47.5\%) female respondents, whose age range differed from fifteen to nineteen. However, it should be noted that majority of respondents were teenagers of sixteen and seventeen. See the pie chart.

They represented mainly 55 (90\%) level 2 students and only $6(10 \%)$ of level 1 students.

In total, the questionnaire contained 32 questions, which were divided into 4 parts accordingly. The questions were designed with the aim to understand the motivation factors of the teenage students while learning English language. There were multiple- 
choice questions as well as open-ended questions in the survey to analyze the motivation factors better.

The participants of the survey were asked to give their opinion based on their practice in learning and improving their English level, how much time they devote to independent learning besides classes at CPFS course, what extra activities they perform; how parents support them at home; whether their parents control their studies or not. Besides, we wanted to know how atmosphere at the CPFS course influence the students; and how the study of hard-working group mates stimulates them. Hence, the questions covered four different areas of motivation.

Score range was divided into five Likert Scale levels as given in Table 1.

Table 1: Score range

\begin{tabular}{|l|l|c|c|}
\hline Scale & Scale Range & Score & Mean Range \\
\hline 1 & Strongly disagree & Lowest & $1.00-1.49$ \\
\hline 2 & Disagree & Low & $1.50-2.49$ \\
\hline 3 & Neither agree nor disagree & Moderate & $2.50-3.49$ \\
\hline 4 & Agree & High & $3.50-4.49$ \\
\hline 5 & Strongly agree & Highest & $4.50-5.00$ \\
\hline
\end{tabular}

\section{Findings}

Table 2: Percentage, mean and standard deviation of personal motivation

\begin{tabular}{|c|c|c|c|c|c|c|c|}
\hline \multirow{2}{*}{ Statements } & \multicolumn{5}{|c|}{ Responses in percentage } & \multirow{2}{*}{ Mean } & \multirow{2}{*}{ S.D. } \\
\hline & SD & D & NAD & A & SA & & \\
\hline I am interested in learning English. & 0 & 0 & 5 & 46 & 49 & 4.44 & 0.59 \\
\hline I practice English every chance I have. & 0 & 5 & 18.6 & 59.3 & 16.9 & 3.88 & 0.74 \\
\hline $\begin{array}{l}\text { I read motivational quotes quite } \\
\text { frequently to inspire myself on the } \\
\text { way of learning English. }\end{array}$ & 3.3 & 8.2 & 18 & 47.5 & 23 & 3.79 & 1.00 \\
\hline $\begin{array}{l}\text { I understand most of spoken English } \\
\text { when I listen to it. }\end{array}$ & 0 & 1.6 & 19.7 & 54.1 & 24.6 & 4.02 & 0.72 \\
\hline $\begin{array}{l}\text { I am confident enough to speak } \\
\text { English during and outside the class. }\end{array}$ & 0 & 9.8 & 18 & 57.4 & 14.8 & 3.77 & 0.82 \\
\hline
\end{tabular}

Overall mean $=3.98$; minimum $=3.77$; maximum $=4.44$; average result $=3.98$ High

SD: Strongly Disagree, D: Disagree, NAD: Neither Agree nor Disagree, A: Agree, SA: Strongly Agree

Table 3: Percentage, mean and standard deviation of parents' motivation

\begin{tabular}{|l|c|c|c|c|c|c|c|}
\hline \multirow{2}{*}{ Statements } & \multicolumn{5}{|c|}{ Responses in percentage } & \multirow{2}{*}{ Mean } & \multirow{2}{*}{ S.D. } \\
\cline { 2 - 7 } & SD & D & NAD & A & SA & & 1.25 \\
\hline My parents speak English. & 11.5 & 27.9 & 29.5 & 14.8 & 16.4 & 2.97 & 1.12 \\
\hline $\begin{array}{l}\text { My parents encourage me to speak } \\
\text { English at home. }\end{array}$ & 6.6 & 9.8 & 36.1 & 27.9 & 19.7 & 3.44 & 0.62 \\
\hline $\begin{array}{l}\text { My parents made all the necessary } \\
\text { conditions, technology available for } \\
\text { me to study English at home. }\end{array}$ & 0 & 0 & 6.6 & 27.9 & 65.6 & 4.59 & \\
\hline
\end{tabular}


Mamadaminova Nigora, Khadjikhanova Sabina

FACTORS INFLUENCING TEENAGER'S MOTIVATION IN LEARNING ENGLISH

IN UZBEKISTAN - A CASE STUDY OF WESTMINSTER INTERNATIONAL

UNIVERSITY IN TASHKENT PRE-FOUNDATION COURSE

\begin{tabular}{|l|c|c|c|c|c|c|c|}
\hline \hline $\begin{array}{l}\text { I study English hard to make my } \\
\text { parents proud of me. }\end{array}$ & 3.3 & 4.9 & 13.1 & 41 & 37.7 & 4.05 & 1.00 \\
\hline $\begin{array}{l}\text { I study English hard because my } \\
\text { parents control my progress most of } \\
\text { the time. }\end{array}$ & 4.9 & 19.7 & 32.8 & 32.8 & 9.8 & 3.23 & 1.04 \\
\hline
\end{tabular}

Overall mean $=3.66$; minimum $=2.97$; maximum $=4.59$; average result $=3.66 \mathrm{High}$

SD: Strongly Disagree, D: Disagree, NAD: Neither Agree nor Disagree, A: Agree, SA: Strongly Agree

Table 4: Percentage, mean and standard deviation of teacher's motivation

\begin{tabular}{|c|c|c|c|c|c|c|c|}
\hline \multirow{2}{*}{ Statements } & \multicolumn{5}{|c|}{ Responses in percentage } & \multirow{2}{*}{ Mean } & \multirow{2}{*}{ S.D. } \\
\hline & SD & D & NAD & A & SA & & \\
\hline $\begin{array}{l}\text { My teacher encourages me to } \\
\text { participate in classroom activities. }\end{array}$ & 3.3 & 3.3 & 16.4 & 45.9 & 31.1 & 3.98 & 0.96 \\
\hline $\begin{array}{l}\text { I am interested in the material } \\
\text { presented during the classes }\end{array}$ & 1.6 & 0 & 18 & 54.1 & 26.2 & 4.03 & 0.77 \\
\hline $\begin{array}{l}\text { My teacher gives us clear instructions } \\
\text { for the tasks. }\end{array}$ & 3.3 & 0 & 6.6 & 55.7 & 34.4 & 4.18 & 0.83 \\
\hline $\begin{array}{l}\text { My teacher uses technology to make } \\
\text { our classes more effective. }\end{array}$ & 1.6 & 0 & 9.8 & 49.2 & 39.3 & 4.25 & 0.77 \\
\hline $\begin{array}{l}\text { I feel comfortable to ask questions } \\
\text { when I do not understand anything } \\
\text { during or after the classes. }\end{array}$ & 0 & 4.9 & 14.8 & 59 & 21.3 & 3.97 & 0.75 \\
\hline
\end{tabular}

Overall mean $=4.08$; minimum $=3.97$; maximum $=4.25$; average result $=4.08$ High

SD: Strongly Disagree, D: Disagree, NAD: Neither Agree nor Disagree, A: Agree, SA: Strongly Agree

Table 5: Percentage, mean and standard deviation of peer motivation

\begin{tabular}{|c|c|c|c|c|c|c|c|}
\hline \multirow{2}{*}{ Statements } & \multicolumn{5}{|c|}{ Responses in percentage } & \multirow{2}{*}{ Mean } & \multirow{2}{*}{ S.D. } \\
\hline & SD & D & NAD & $\mathbf{A}$ & SA & & \\
\hline $\begin{array}{l}\text { I practice English together with my group mates } \\
\text { after or before BEAP classes. }\end{array}$ & 0 & 9.8 & 26.2 & 36.1 & 27.9 & 3.82 & 0.96 \\
\hline $\begin{array}{l}\text { I met very talented and bright students at CPFS } \\
\text { course who motivate me to study harder. }\end{array}$ & 3.3 & 4.9 & 14.8 & 59 & 18 & 3.84 & 0.89 \\
\hline $\begin{array}{l}\text { I learnt a lot from my group mates here at CPFS } \\
\text { course. }\end{array}$ & 3.3 & 4.9 & 24.6 & 45.9 & 21.3 & 3.77 & 0.95 \\
\hline $\begin{array}{l}\text { We have a healthy competition among group } \\
\text { mates at CPFS course. }\end{array}$ & 1.6 & 3.3 & 13.1 & 55.7 & 26.2 & 4.01 & 0.83 \\
\hline $\begin{array}{l}\text { My group mates/friends at CPFS support me when } \\
\text { I miss some classes. }\end{array}$ & 1.6 & 6.6 & 14.8 & 54.1 & 23 & 3.90 & 0.89 \\
\hline
\end{tabular}

Overall mean $=3.86$; minimum $=3.77$; maximum $=4.01$; average result $=3.86 \mathrm{High}$

SD: Strongly Disagree, D: Disagree, NAD: Neither Agree nor Disagree, A: Agree, SA: Strongly Agree

\section{Discussion}

The findings indicate that teenage students are mostly motivated by their teachers $(\mathrm{m}=4.08)$. It is observed from the responses that majority of the students are enjoying the course and satisfied with the delivery and classroom management skills of their teacher. Besides, nearly $87 \%$ students agreed that they are encouraged to have enough interaction 
during the classes and almost $84 \%$ of them approved the fact that they have warm atmosphere at the course, which also influences the general motivation of the students to study English further. Many investigations approve the same fact that teachers are the first source of motivation for language learners. For example, the same result was noted from the study in India (Olusiji, 2016) while the level of motivation and support students receive from their teachers, parents and peers was analyzed. Moreover, the result of the current research is in line with the findings of Ekiz and Kulmetov (2016) where it was stated that there was a remarkable interconnection between students' motivation and teachers' strategies. Furthermore, Gilakjani et al. (2012) claimed that motivation is the most important part of teachers' job to support students find opportunities for engaging learning tasks outside the classroom. Therefore, teachers are recommended to develop their professional skills constantly to encourage students to become more active learners (Sant, 2018). Moreover, certain strategies are suggested for teachers by researchers, such as setting clear goals, showing the need for the lesson, maintaining students' interest, being a professional and role model, treating learners as special individuals, using teachings methods which are interesting and stimulating, challenging the students, encouraging healthy competition among students and others (Filgona et al., 2020).

At the same time, it is important to highlight that students also motivate their teachers. According to the investigation made by Hettiarachchi (2013) in Sri Lanka among English language teachers, teachers feel motivated by students' performance, students' positive attitude towards learning English, students' recognition and appreciation of their hard work.

Interestingly after the teachers, factor, which influences students' motivation, is themselves. So teenage students of CPFS course are very self-motivated $(m=3.98)$. The same result was found in the research conducted among the English language learners in Malaysia by Abdul Rahman et al (2017), where it was found that after teachers, students are their own motivators. Moreover, it was observed that $39 \%$ of students have been learning English for more than three years, while 13\% students started learning the language less than a year ago. Almost all students (95\%) are interested in learning English and less than half of them spend three to five hours a week practicing English independently. Even 10\% of them study English individually about nine to 12 hours a week. In their free time, students of CPFS course mainly watch films of various shows in English (65.6\%), and listen to the songs and translate them (54.1\%). Reading books and chatting to foreign peers in social networking sites as well as listening to podcasts and lectures in English are also activities that students perform to improve their skills. It was interesting to find out that nearly $20 \%$ of respondents strengthen their language skills by teaching English to their siblings or nephews. When students were also asked about their last book or magazine, they have read in English, it was a pleasure to learn that they read books such as "Harry Potter", "The Adventures of Sherlock Holmes", "Who will cry when you die", "Rich dad poor dad" and magazines such as "Forbes", "Economist", and newspaper "New York Times". Moreover, different short stories were also a frequent 
answer given by students. Finally, they explained the reasons of their interest in English. The first reason to study English is related to their future occupation and secondly their willingness to study abroad. Then they indicated that they need it for travelling and communication with foreign people and even some of the students stated that they wish to immigrate to an English speaking country. Thus, students' self-motivation could be also explained based on their awareness of the importance of learning and speaking a foreign language. As stated in the study performed by Dr. Mahadi and Jafari (2012), students have high motivation when they realize the value of learning and they can get the benefits of learning the language in order to achieve their future goals. Students of the CPFS course understand the value of acquiring this knowledge and they have a positive view about their efforts to learn English.

The third motivators of the respondents turned out to be their peers $(m=3.86)$. Over $92 \%$ of students consider that they are in good relationship with their group mates at CPFS course. $82 \%$ of them agreed to the statement that they have a healthy competition among students, which is an indicator that course administration and teachers created good conditions and healthy environment for students to improve their language skills. Besides, the majority of the students help each other when they do not understand some topics and they claimed that they are positively influenced by achievement of their group mates at CPFS. However, not always the peers have been the great influencers in the process of acquiring knowledge of a foreign language. The researchers conducted previously to estimate the role of peers as motivators were different. According to the studies of Csizer and Kormos (2008) and Iwaniec (2014), peers had little impact on language learning. Nevertheless, the current study shows that peers have more influence than parents do.

The last motivators are parents according to the research results (3.66). The current study demonstrated that $31 \%$ of parents of teenage students of CPFS know English language well enough that they can correct mistakes of their children. Over $47.5 \%$ of respondents agreed to the fact that their parents encourage them to speak English at home. Moreover, $72 \%$ of parents buy books or magazines in English for their children. ${ }^{\text {ii }}$ Furthermore, we wanted to know the number of students who study so hard to impress their parents or because parents control their studies. Nearly $78 \%$ of respondents' study hard to make their parents proud of them whereas only over $8 \%$ of them disagreed with their peers on this statement. Just $25 \%$ of students argued that they do not study hard because their parents control their progress all the time. The rest $42 \%$ of respondents mainly accepted the control of parents while another 33\% felt neutral about it. The results also demonstrate that $77 \%$ of parents encouraged their teenage children to attend CPFS course in order to get better preparation to their future studies and improve their English language skills.

\footnotetext{
ii It should be also noted that parents still have huge influence in their children's life, decisions related to their studies, future profession and even marriage in Uzbek societies.
} 
Based on the collected responses from students of CPFS course, gender and agebased analysis were also made. The results of data analysis show that there are no statistically significant differences between self-motivation of male and female students. The same outcome was supported by the research by Akram and Ghani in Pakistan in 2013. Furthermore, it was very interesting to find out that female students feel less control by their parents (24\%) compared to male students $(59 \%)$. The reason for this might be the fact that in Uzbek culture unfortunately, it can be observed that parents and grandparents spoil their sons and at the same time, they tend to be stricter towards their daughters. So, this tendency can be noticed from the results too, when sons get older, they need to be under control so that they study well, whereas daughters have learnt to manage their studies and are already brought up responsible students compared to boys. ${ }^{\text {ii }}$

Furthermore, in the age-based analysis, respondents were divided into two groups (Group 1 - respondents at the age of 15 and 16; Group 2 - respondents at the ages from 17 to 19). According to the results, group 2 felt more confident in speaking English (77\%) compared to Group 1 (69.5) which can be explained by the overall exposure to using English language and practicing it. Another higher discrepancy in the responses between two groups could be observed again in the question related to parents' control. Group 2 has higher rate of control by their parents (58\%) than Group 1 (35\%). It might be because of their age and in Uzbekistan, it is not favored to have a gap year before entering university, so parents try to assign private tutors or register children to different courses to prepare their children to the university. Thus, group 2 respondents belong to the age when it is time to enter university or who have failed to enter higher educational institutions in previous year/years according to the Uzbek culture.

\section{Conclusion}

The current study showed that the highest influencers in learning English are teachers. However, it should be emphasized that the next highest motivators were students themselves and then their peers. Based on the results, it is advised for teachers to upgrade their teaching skills keeping in mind that they are the greatest motivators of students and they play enormous role in students' future endeavors. Moreover, more spaces for students' collaboration in the university premises would bring more advantages to the overall satisfaction of students.

Uzbekistan being a developing country and the government paying more attention to the knowledge of foreign languages, it can be concluded that Uzbek youth are very much interested in learning English as a foreign language, and they understand the opportunities it may bring in their future.

\section{Conflict of Interest Statement}

The authors declare no conflicts of interests.

iii This topic could be better investigated in further studies. 


\begin{abstract}
About the Authors
Nigora Mamadaminova has a master's degree at Westminster International University in Tashkent and her research interests include such areas as distance education, preschool education, classroom management, students' motivation, women empowerment and culture. orcid.org/0000-0002-0422-8585
\end{abstract}

Sabina Khadjikhanova has a master's degree at Tashkent State Institute of World Languages and works as an associate lecturer at Westminster International University in Tashkent. Her research interests are students' motivation, building rapport with students, students' satisfaction, and assessment. orcid.org/0000-0001-9515-638X

\title{
References
}

Abdul Rahman, H., Rajab, A., Abdul Wahab, S., Mohd Nor, F., Wan Zakaria, W. and Asyraf Badli, M. (2017). Factors Affecting Motivation in Language Learning. International Journal of Information and Education Technology, 7(7), pp.543546.

Akram, M. and Ghani, M. (2013). Gender and language learning motivation. Academic Research International, 4(2), pp.536-540.

Al Mardhiyyah, S., Latief, M. and Masduqi, H. (2021). Enhancing the Students' Learning Motivation by Using Instructional Media for Thailand's Municipal School. Pedagogy : Journal of English Language Teaching, 9(1), p.76.

Ametova, O. (2020). The Influence of Integrative Motivation and Instrumental Motivation on Learning English as a Foreign Language. Journal of critical reviews, 7(12). pp.942945.

Cenić, D., Petrović, J. and Cenić, S. (2018). The Most Important Motivation Factors for Knowledge Acquistion and Successful Learning. Teaching, Learning and Teacher Education, 2(2), pp.149-159.

Csizer, K and Kormos, J. (2008). An overview of Hungarian secondary school students' foreign language motivation. In H.V. Knudsen (Ed.), Secondary School Education, pp. 65-87.

Ekiz, S. and Kulmetov, Z. (2016). The Factors Affecting Learners' Motivation in English Language Education. Journal of Foreign Language Education and Technology, 1(1), pp.18-38.

Filgona, J., Sakiyo, J., Gwany, D. and Okoronka, A. (2020). Motivation in Learning. Asian Journal of Education and Social Studies, pp.16-37.

Ghazi, S., Ali, R., Shahzad, S. and Hukamdad, H. (2010). Parental Involvement in Children Academic Motivation. Asian Social Science, 6(4).

Gilakjani, A., Leong, L. and Sabouri, N. (2012). A Study on the Role of Motivation in Foreign Language Learning and Teaching. International Journal of Modern Education and Computer Science, 4(7), pp.9-16. 
Gilakjani, A., Leong, L. and Sabouri, N. (2012). A Study on the Role of Motivation in Foreign Language Learning and Teaching. International Journal of Modern Education and Computer Science, 4(7), pp.9-16.

Guay, F., Chanal, J., Ratelle, C. F., Marsh, H. W., Larose, S., \& Boivin, M. (2010). Intrinsic, identified, and controlled types of motivation for school subjects in young elementary school children. British Journal of Educational Psychology, 80(4), 711735.

Hettiarachchi, S. (2013). English Language Teacher Motivation in Sri Lankan Public Schools. Journal of Language Teaching and Research, 4(1).

Iwaniec, J. (2014). Motivation of pupils from southern Poland to learn English. System, 45, pp.67-78.

Johnson, D.(2017). The Role of Teachers in Motivating Students to Learn. BU Journal of Graduate Studies in Education, 9(1), pp.46-49.

Jowkar, M., Nekuruh Motlagh, L. and Mirshamsi, F. (2017). Types of Motivation in Iranian EFL learners toward English Language Learning. Journal of English Language and Literature, 7(3), p.560.

Mackey, A. (2014). Wanting it enough: why motivation is the key to language learning. [online] The Guardian. Available at: https://www.theguardian.com/education/2014/jun/26/motivation-key-languagelearning [Accessed 27 July 2021].

Mahadi, D. and Jafari, S. (2012). Motivation, Its Types, and Its Impacts in Language Learning. International Journal of Business and Social Science, 3(24), pp.230-235.

Muh. Arief, M. (2015). Using Task-Based Approach in Improving the Students' Speaking Accuracy and Fluency. Journal of Education and Human Development, 4(3), pp.181190.

Nir, A. E. (2002). School-based management and its effect on teacher commitment. International Journal of Leadership in Education, 5, 323-341.

Nur Saroh, TE. 151602 and Hayat, Najmul and Taridi, M. (2019). The Students' Interest in Learning English at The Tenth Grade of Senior High School 7 Jambi City. Skripsi thesis, Uin Sulthan Thaha Saifuddin Jambi.

Ofoegbu, F. I. (2004) Teacher motivation: a factor for classroom effectiveness and school improvement. College Student Journal, 38, 81-89.

Okoza, J., Aluede, O. and Afen Akpaida, J. (2012). Secondary School Students' Perception of Environmental Variables Influencing Academic Performance in Edo State, Nigeria. Bangladesh e-Journal of Sociology, 9(2), pp.84-94.

Olusiji, L.(2016). Parents, Teachers and Peers Effects on College Students' Motivational Intensity to Learn English. Language in India, 16(4), pp.61-81.

Olusiji, L. (2021). Parents, Teachers and Peers Effects on College Students' Motivational Intensity to Learn English. Journal of Educational Psychology, pp.61-80.

Pape, B. (1999). Involving Parents Lets Students and Teachers Win. Education Digest, 64(6), 47-51. 
Reiss, S. (2012). Intrinsic and Extrinsic Motivation. Teaching of Psychology, 39(2), pp.152156.

Sant, N. (2018). A Study on Factors Affecting Students' Motivation in the English Language Classrooms at Maija Yang Institute of Education, Kachin State, Myanmar. Language in India, 18(4), pp.199-220.

Tianjuan, Z. (2019). Methods of Stimulating Students' Interest in English Learning. Advances in Social Science, Education and Humanities Research, 314, pp.472475.

Win, M. M. (2018). Motivational Factors to Promote Students' Interest and Involvement in Teaching-Learning English. People: International Journal of Social Sciences, 4(3), 224-237.

Ziahosseini, S. and Salehi, M. (2008). An Investigation of the Relationship between Motivation and Language Learning Strategies. Pazhuhesh-e Zabanha-ye Khareji, 41, pp.85-107.

Author(s) will retain the copyright of their published articles agreeing that a Creative Commons Attribution 4.0 International License (CC BY 4.0) terms will be applied to their work. Under the terms of this license, no permission is required from the author(s) or publisher for members of the community to copy, distribute, transmit or adapt the article content, providing a proper, prominent and unambiguous attribution to the authors in a manner that makes clear that the materials are being reused under permission of a Creative Commons License. Views, opinions, and conclusions expressed in this research article are views, opinions, and conclusions of the author(s). Open Access Publishing Group and European Journal of Foreign Language Teaching shall not be responsible or answerable for any loss, damage, or liability caused in relation to/arising out of conflicts of interest, copyright violations, and inappropriate or inaccurate use of any kind content related or integrated into the research work. All the published works are meeting the Open Access Publishing requirements and can be freely accessed, shared, modified, distributed, and used in educational, commercial, and non-commercial purposes under a Creative Commons Attribution 4.0 International License (CC BY 4.0). 